\title{
TERAPI KOGNITIF PERILAKU RELIGIUS UNTUK MENURUNKAN KECEMASAN TERHADAP KEMATIAN PADA PENDERITA HIV/AIDS
}

\section{RELIGIOUS COGNITIVE BEHAVIOR THERAPY TO REDUCE THE ANXIETY TOWARDS DEATH OF HIV / AIDS PEOPLE}

\author{
Deasy Irawati \\ Fakultas Psikologi dan IImu Sosial Budaya Universitas Islam Indonesia Yogyakarta \\ E-mail: deasy_psikologi@yahoo.com
}

\section{Subandi}

Fakultas Psikologi Universitas Gadjah Mada Yogyakarta

\section{Retno Kumolohadi}

Fakultas Psikologi dan IImu Sosial Budaya, Universitas Islam Indonesia

\begin{abstract}
This study was aimed to understand the effect of giving religious cognitive cognitive therapy in reducing anxiety of death in people with HIV / AIDS. There are 8 woman with HIV / AIDS as subject. The data was collected using a scale of anxiety about death, interviews and observation. The design of the study is a pretest-posttest Control Group Design. Analysis of the study is a quantitative and qualitative analysis. The research used Mann-Whitney test analysis to determine whether there is influence of cognitive behavioral therapy in reducing anxiety to wards religiously death of people with HIV / AIDS in the study group before and after being given the training provided the training. Qualitative analysis are based on observations, interviews, and worksheets. The results of the pre-test and post test anxiety on mortality suggests that there are differences in anxiety about the death after being given training by the value $Z=-2.309, p=0.021, p<0.05$. In the post test and follow-up of research groups there are differences in anxiety about death with a value of $Z=-2.323, p=0.020$, $p<0.05$. The conclusion of this study is that there are differences in levels of anxiety towards death on the subject after the follow-up study.
\end{abstract}

Key words: religious cognitive behavioral therapy, anxiety towards death, HIV / AIDS 


\section{ABSTRAK}

Penelitian ini bertujuan untuk mengetahui pengaruh pemberian terapi kognitif perilaku religius dalam menurunkan kecemasan terhadap kematian pada penderita HIV/AIDS. Subjek Penelitian berjumlah 8 orang penderita HIV/AIDS berjenis kelamin perempuan. Pengumpulan data dilakukan dengan menggunakan skala kecemasan terhadap kematian, wawancara dan observasi. Rancangan penelitian yang digunakan adalah Pretest-Posttest Control Group Design. Analisis penelitian yang digunakan adalah analisis kuantitatif dan kualitatif. Analisis kuantitatif dengan uji hipotesis menggunakan analisis uji Mann-Whitney untuk mengetahui ada tidaknya pengaruh terapi kognitif perilaku religius dalam menurunkan kecemasan terhadap kematian pada penderita HIV/AIDS pada kelompok penelitian sebelum diberikan pelatihan dan setelah diberikan pelatihan. Analisis kualitatif dilakukan berdasarkan hasil observasi, wawancara, lembar kerja. Hasil penelitian yaitu pada prates dan pascatest kecemasan terhadap kematian menunjukkan bahwa ada perbedaan kecemasan terhadap kematian setelah diberikan pelatihan dengan nilai $Z=-2,309, p=0,021, p<0,05$. Pada pascates dan follow-up kelompok penelitian terdapat perbedaan kecemasan terhadap kematian dengan nilai $Z=-2,323, p$ $=0,020, p<0,05$. Kesimpulan penelitian ini adalah ada perbedaan tingkat kecemasan terhadap kematian pada subjek penelitian setelah dilakukan follow-up.

Kata kunci: terapi kognitif perilaku religius, kecemasan terhadap kematian, penderita HIV/AIDS.

Acruired Immune Deficiensy Syndrome atau yang lebih dikenal dengan istilah AIDS merupakan penyakit yang ditandai dengan adanya kelainan yang komplek dalam sistem pertahanan selular tubuh dan menyebabkan korban menjadi sangat peka menghadapi mikroorganisme oportunistik. Penyakit AIDS disebabkan oleh Human Immunodeficiency Virus atau disingkat dengan HIV. Penyakit ini merupakan penyakit kelamin, yang pada mulanya dialami oleh kelompok kaum homoseksual. AIDS pertama kali ditemukan di Kota San Francisco, Amerika Serikat. Penyakit ini muncul karena hubungan seksual (sodomi) yang dilakukan oleh komunitas kaum homoseksual (Hawari, 2006).
Penyakit HIV/AIDS merupakan penyakit kronis paling berbahaya sekarang ini. Saat ini tidak ada satu negara pun di muka bumi ini mengaku bahwa negaranya terbebas dari keganasan penyakit HIV/AIDS. Penyakit ini sudah menyebar merata di negara maju dan negara dunia ketiga di seluruh dunia.

Pada awal perkembangannya sekitar tahun 1970, penyakit HIV/AIDS masih dipandang sebagai sebuah epidemi yang hanya mewabah pada wilayah tertentu dan hanya pada golongan atau kelompok tertentu saja. Akan tetapi seiring dengan berjalannya waktu, penyakit ini sudah berubah menjadi sebuah pandemi yang menyebar dengan sangat cepat dengan cakupan wilayah penyebaran yang 
semakin luas tidak hanya pada satu wilayah dan golongan tertentu tetapi sudah merata pada semua golongan masyarakat tanpa terkecuali pada individu yang dianggap tidak mungkin terkena penyakit HIV/AIDS.

Laksono (Puji, 2010), mengatakan hingga 30 September 2010 jumlah kasus AIDS secara kumulatif tercatat 22.726 kasus yang tersebar di 33 propinsi di 300 kabupaten/kota. Individu-individu yang terkena HIV/AIDS masih didominasi oleh kelompok usia produktif (20-29 tahun) sebanyak $47,8 \%$, kelompok umur produktif (30-39 tahun) sebanyak 30,9\%, dan kelompok umur produktif (40-49 tahun) sebanyak 9,1\%. Kasus terbanyak terjadi di sepuluh propinsi yakni DKI Jakarta, Jawa barat, Jawa Tengah, Jawa Timur, Papua, Bali, Kalimantan Barat, Sulawesi Selatan, Sumatera Utara dan Riau. Cara penularan terjadi melalui hubungan heteroseksual (51,3\%), pengguna narkoba suntik $(39,6 \%)$, lelaki dengan lelaki $(3,1 \%)$ dan ibu pengidap kepada bayinya $(2,6 \%)$.

Di Provinsi D.I. Yogyakarta, berdasarkan data yang dilaporkan oleh Ditjen PPM dan PL Departeman Kesehatan RI sampai Maret 2010 secara komulatif kasus HIV/AIDS yang dilaporkan berjumlah 290 individu. Rinciannya 132 penderita masih hidup dan 81 penderita meninggal, sedangkan prevalensi kasusnya sendiri mencapai $8,51 \%$ per 100.000 penduduk.
Kementerian Kesehatan menyatakan sebanyak 1,6 juta ibu/perempuan di Indonesia berpotensi tertular HIV/ AIDS. Ironisnya, penular mereka adalah suami mereka sendiri. Hal ini terungkap berdasarkan data terkini, yaitu terdapat 3,2 juta laki-laki yang menggunakan jasa seks komersial. Dari 50\% laki-laki tersebut sudah berkeluarga, berarti $50 \%$ istri dan ibu-ibu di rumah terancam tertular HIV/AIDS. Hal itu didukung oleh data Kementrian Kesehatan sampai September 2010 bahwa penularan HIV/ AIDS melalui hubungan heteroseksual atau lebih dari satu pasangan mencapai $51,3 \%$; penularan melalui penggunaan jarum suntik lebih rendah sebesar 39,6\%. Tingginya kasus penularan terhadap ibu rumah tangga melalui heteroseksual menurut Subuh (2010) dipengaruhi oleh kerentanan perempuan untuk tertular. Kerentanan itu disebabkan di antaranya oleh tingkat pengetahuan tentang penularan HIV AIDS perempuan yang rendah dan juga faktor ekonomi di mana perempuan masih tergantung secara ekonomi terhadap suami sehingga perempuan yang tertular sulit untuk mengakses kesehatan (Puji, 2010).

Sebuah prediksi tentang penyebaran HIV menunjukkan bahwa sekitar tahun 2002-2010 diduga akan ada penambahan jumlah individu yang terkena HIV berkisar antara 45 jutaan di 126 negara yang berpenghasilan rendah. Dipastikan angka tersebut tidak akan tercapai sepenuhnya 
seandainya masyarakat dunia secara cepat dan efektif menurunkan angka kesakitan kerena penyakit HIV ini melalui strategi pencegahan secara global. Lebih lanjut, $40 \%$ dari perkiraan pertambahan individu yang terkena HIV tersebut terjadi di Asia dan sekitar Pasifik (Maramis \& Nasrudin, 2007).

Mencermati angka statistik dari tahun ke tahun tersebut, jelas sekali ada pola peningkatan yang signifikan dari penyebaran HIV/AIDS di Indonesia. Diyakini bahwa angka kasus yang ditemukan dan dilaporkan tidak menunjukkan keadaan angka yang nyata terjadi di lapangan, karena penyebaran penyakit HIV/AIDS di masyarakat layaknya fenomena gunung es. Artinya angka kasus yang belum ditemukan/ dilaporkan jauh lebih banyak dari angka yang ditemukan.

Tidak dapat dipungkiri bahwa masalah HIV/AIDS ini bukan saja masalah yang selalu didominasi oleh permasalahan kesehatan, tetapi sudah melebar pada permasalahan dan konsekuensi pada bidang yang lain seperti ekonomi, politik, sosial, etis agama, hukum dan psikologis. Sebab masalah ini akan menyentuh semua aspek kehidupan berbangsa dan bernegara, dan ini merupakan ancaman yang nyata bagi seluruh masyarakat Indonesia untuk bisa berusaha meningkatkan kembali kualitas sumber daya manusianya (Djauzi, 1997).
Terdapat berbagai macam reaksi yang muncul ketika individu dinyatakan HIV Positif. Menurut Djauzi (1997), reaksi penderita HIV/AIDS tersebut terbentuk dari kecemasan dan kekhawatiran yang berkecamuk dalam diri penderita tentang pasangan yang akan meninggalkan atau mengabaikan dirinya, kemungkinan akan di PHK (Pemutusan Hubungan Kerja) tanpa kejelasan masa depan, dan kurangnya informasi tentang bagaimana cara mendapatkan dan memanfaatkan perawatan medis yang tersedia. Dijelaskan lebih lanjut olehnya, bahwa setiap penderita HIV/AIDS akan sangat beragam reaksinya ketika menghadapi keadaan penyakit HIV/AIDS, di antaranya menyangkal terkena HIV, takut, cemas, dan depresi, bahkan ada yang berpikir akan melakukan bunuh diri atau minta untuk dibunuh.

Sebuah hasil penelitian memaparkan hasil penelitiannya bahwa begitu individu terinfeksi AIDS (atas pemberitahuan Dokter), penderita mengalami shock yang menyebabkan penyakit makin lama makin berat, timbul berbagai infeksi oportunistik, sehingga penderita makin tersiksa. Hal utama yang menyebabkan shock yang dialami penderita adalah kecemasan terhadap kematian. Meskipun ini tidak mengesampingkan berbagai kecemasan lain yang dihadapi penderita, misalnya kecemasan karena biaya pengobatan tambah besar, macam 
penyakit tambah banyak, obat yang diberi harus tambah banyak dan tambah keras dengan berbagai efek samping yang memperparah keadaan penderita, ungkapan di atas sesuai dengan hasil wawancara terhadap subjek prasurvei yang dilakukan oleh peneliti.

Gangguan kejiwaan yang membayangi penderita HIV/AIDS tersebut oleh Djoerban (1999) dikelompokkan menjadi empat jenis gangguan, yaitu gangguan afektif seperti depresi berat, kemudian gangguan kecemasan menyeluruh, yang ketiga keinginan untuk bunuh diri, dan yang terakhir gangguan otak organik yang mewujud bentuk delirium atau demensia primer yang disebabkan adanya infeksi oportunistik.

Menurut Green (2003), penyakit HIV/ AIDS dipandang sebagai penyakit yang belum ada obatnya dan selalu dikaitkan dengan proses kematian yang begitu cepat. Padahal, kenyataannya penderita HIV/AIDS dapat hidup sehat dalam kurun waktu yang sangat lama, bahkan melebihi perkiraan jatah hidup penderita yang hanya berkisar 5 sampai 10 tahun. Banyak cara yang dapat ditempuh supaya kualitas hidup dan kekebalan tubuh tidak berkurang dan penderita tidak termasuk dalam kelompok rentan terhadap serangan penyakit infeksi oportunistik dan depresi. Saat ini tersedia banyak bentuk pengobatan alternatif yang ditawarkan dan dapat dijadikan pengobatan alternatif untuk meningkatkan sistem kekebalan, kualitas hidup penderita HIV/AIDS seperti pijat refleksi, meditasi, terapi, pemberian suplemen vitamin, dan olahraga pernafasan.

Pemikiran dan perenungan terhadap kematian sebenarnya bukanlah hal baru dalam sejarah manusia. Agama-agama besar dan aliran kepercayaan terhadap Tuhan Yang Maha Esa selalu mengangkat tentang tema kematian sebagai suatu bagian yang sangat penting. Kematian adalah kejadian penting dalam aspek spiritualitas. la dipercaya sebagai suatu kepastian (Q.S. 3:183, 21:34), dan pintu menuju keabadian (Q.S. 29:64, 14:77, 9:38) di mana kehidupan setelah kematian adalah kehidupan yang kekal dan abadi.

Banyak faktor yang membuat seseorang takut mati. Ketakutan itu karena manusia tidak mengetahui apa yang akan dihadapinya setelah kematian, karena menduga bahwa yang dimiliki sekarang lebih baik dari yang akan didapatkan nanti, karena membayangkan betapa sulit dan pedih pengalaman mati dan sesudah mati, karena khawatir memikirkan dan prihatin menghadapi keluarga yang akan ditinggalkan, atau karena kurangnya pemahaman menghadapi makna hidup dan mati, dan sebagainya, sehingga menimbulkan perasaan takut dan cemas dalam menghadapi kematian. Bond (Wicaksono, 2003) menyatakan bahwa seseorang yang tidak menemukan tujuan atau kegunaan (purpose) dalam kehidupannya, kematian akan 
menjadi suatu pengalaman yang sangat mencemaskan, sedangkan Schaice dan Willis (Wicaksono, 2003) berpendapat bahwa kecemasan terhadap kematian adalah suatu hal yang berkaitan dengan berbagai faktor seperti usia, keyakinan religius, dan tingkat di mana individu mempunyai kehidupan yang memuaskan.

Kecemasan yang berlebihan terhadap kematian seringkali menimbulkan gangguan fungsi-fungsi emosional normal manusia. Penelitian menunjukkan keterkaitan positif antara kecemasan terhadap kematian dengan gangguan emosional seperti neurotisme, depresi, gangguan psikosomatis (Feifel \& Nagy, 1981). Pentingnya penelitian terhadap kecemasan terhadap kematian menyadarkan pada premis bahwa setiap manusia akan mati. Selain itu, dampak negatif muncul dari kecemasan akan kematian ini banyak menimbulkan akibat yang seharusnya tak perlu terjadi.

Kenyataan bahwa HIV/AIDS berujung pada kematian pastilah disadari oleh setiap individu yang menderitanya. Kesadaran akan kematian diri sendiri dapat memunculkan perasaan takut atau cemas akan kematian (Adelbratt \& Strang, 2000). Padahal kecemasan terhadap kematian dapat memberikan dampak negatif bagi individu. Beberapa penelitian menunjukkan bahwa kecemasan terhadap kematian memiliki hubungan yang signifikan dengan psychological distress (Templer dkk, dalam Chung \& Easthope, 2000).
Strategiyangefektiftentangkecemasan terhadap kematian banyak dilakukan. Salah satunya adalah mengembangkan kebijakan dan religiositas individu, di mana religiositas hampir selalu dikaitkan dengan terciptanya kondisi psikologis yang positif (psychological well being). Termasuk juga di dalamnya adalah kecemasan terhadap kematian.

Menurut Leming (Wicaksono, 2003), religiositas memiliki peran penting dalam menghalau kecemasan dan kecemasan yang terjadi sebagai akibat dari ketidakpastian dan ketidaktahuan yang dialami dalam hidup. Lebih jauh ia berpendapat bahwa keyakinan religius memiliki hubungan yang negatif terhadap kecemasan terhadap kematian, di mana orang yang memiliki motivasi religius yang tinggi akan memiliki kecemasan terhadap kematian yang rendah.

Kehidupan religius atau keagamaan menurut Najati (1985) dapat membantu manusia dalam menurunkan kecemasan, kegelisahan, dan ketegangan. Sejalan dengan pendapat di atas, Maududi dan Spink (Wicaksono, 2003) mengatakan bahwa salah satu peran religiositas adalah menimbulkan ketenangan kalbu, sebab dalam diri setiap individu terdapat insting atau naluri yang disebut sebagai religius insting, yaitu suatu naluri untuk meyakini dan mengadakan penyembahan menghadapi suatu kekuatan yang ada di luar diri seorang individu. Naluri ini kemudian mendorong seorang individu untuk mengadakan kegiatan-kegiatan religius. 
Terapi kognitif perilaku adalah suatu proses pengajaran, pelatihan, dan penguatan perilaku yang positif. Terapi kognitif perilaku ini menolong orang untuk mengenali pola kognitif atau pikiran emosi yang berhubungan dengan perilaku. Konsep terapi kognitif perilaku ini menggunakan emosi dan perilaku dihasilkan dari proses pikiran. Manusia dapat mengubah proses ini untuk mendapatkan cara merasa dan berperilaku yang berbeda (Froggatt, 2006).

Teknik modifikasi kognitif perilaku ini merupakan teknik yang sudah berkembang pesat sejak dekade yang lalu dengan penggabungan modifikasi perilaku dan terapi kognitif. Terapi ini berkembang sangat pesat sejak 10 tahun terakhir ini. Modifikasi kognitif perilaku didasarkan pada asumsi bahwa perilaku manusia secara resiprok dipengaruhi oleh pemikiran, perasaan, proses fisiologis, serta konsekuensinya pada perilaku. Jadi bila ingin mengubah perilaku yang maladaptif dari manusia, maka tidak hanya sekedar mengubah perilakunya saja, namun juga menyangkut aspek kognitifnya. Modifikasi kognitif perilaku terdiri dari berbagai prosedur pelatihan yang berbeda-beda, termasuk di dalamnya antara lain relaksasi, terapi kognitif, dan pemantauan diri (Meichenbaum, 1989). Sementara itu menurut Keefe dkk (1992), terapi kognitif perilaku dapat secara efektif membantu pasien dengan penyakit kronis.
Berbagai macam bentuk terapi perilaku yang sudah ada adalah relaksasi otot, relaksasi kesadaran indera, relaksasi meditasi, yoga dan relaksasi hipnosa dari bentuk relaksasi di atas pernah dimunculkan kajian tentang bentuk relaksasi religius. Relaksasi religius ini merupakan pengembangan metode respon relaksasi dengan melibatkan faktor-faktor relaksasi religius Benson (2000), di mana formula-formula tertentu yang dibaca berulang-ulang dengan melibatkan unsur keimanan kepada agama, kepada Tuhan yang disembah akan menimbulkan respon relaksasi yang lebih kuat dibandingkan dengan sekedar relaksasi tanpa melibatkan unsur keyakinan menghadapi hal tersebut.

Dalam penelitian ini dikembangkan sebuah terapi kognitif perilaku religius, yakni penggabungan teknik terapi perilaku dengan memasukkan faktor keyakinan. Pada penelitian ini unsur keyakinan yang akan dipergunakan dalam intervensi adalah unsur keyakinan dan dasar-dasar agama Islam. Unsur keyakinan yang dimasukkan dalam penelitian ini adalah penyebutan Allah secara berulang-ulang yang disertai dengan sikap pasrah. Tujuan terapi ini adalah mengubah pikiran atau keyakinan klien yang irasional, maladaptif tidak produktif, dan melemahkan, serta mengadopsi dan memperkuat keyakinan dan pikiran yang lebih membangun berdasarkan nilai-nilai Islam. 
Dalam penanggulangan masalah, agama menjadi bagian penting, yaitu dalam pengalaman penting religius, penilaian agama, aktivitas penanggulangan religius, dan tujuan religius dalam penanggulangan sehingga dalam proses terapi agama menjadi suatu dasar dalam penilaian, aktivitas, dan tujuan yang ditetapkan oleh individu dalam menghadapi kondisi kehidupan (Pargament dkk., 1998).

Terapi religiositas dapat dikatakan memiliki hubungan terhadap terapi kognitif perilaku. Hal tersebut dapat dijelaskan bahwa terapi kognitif perilaku bertujuan memberikan metode terapi kepada individu melalui perubahan kognitif yang salah menuju kognitif yang positif sehingga diharapkan akan memunculkan perilaku yang baru yang lebih baik dari sebelumnya. Perubahan tersebut hanya bersifat sementara, sehingga diperlukan suatu penguat yang selalu dilakukan oleh individu dalam rentang waktu yang lama, seperti sebuah keyakinan yaitu agama. Agama akan memunculkan tingkat religiositas seorang individu, jadi diasumsikan bahwa ketika religiositas individu muncul karena menjalankan kegiatan keagamaan maka akan memunculkan pola kognitif yang positif secara bersamaan sehingga akan membentuk perilaku yang positif juga. Jadi dapat disimpulkan bahwa terapi religiositas akan mendukung dan memperkuat terapi kognitif perilaku karena akan dilakukan secara terus menerus dan berkelanjutan.

Metode terapi ini sejauh pengetahuan penulis belum pernah dilakukan terutama untuk intervensi kecemasan terhadap kematian pada penderita HIV/AIDS, sehingga penelitian ini ditujukan untuk melihat lebih jauh tentang efektifitas terapi kognitif perilaku religius untuk menurunkan kecemasan terhadap kematian. Hasil dari penelitian ini diharapkan dapat menambah model terapi kognitif perilaku terutama untuk menurunkan kecemasan terhadap kematian pada penderita HIV/AIDS. Terapi perilaku religius sebagai sebuah terapi dapat menjadi referensi untuk menurunkan kecemasan terhadap kematian terutama bagi mereka yang memiliki keyakinan agama Islam, selain itu hasil penelitian ini dapat digunakan untuk pengembangan psikologi Islam. Diharapkan dengan adanya terapi kognitif perilaku religius akan memberikan integrasi raga (fisik \& biologi), mental, jiwa, dan spirit melalui transformasi kesadaran, sehingga terjadi keharmonisan atau keselarasan.

Hipotesis yang diajukan dalam penelitian ini adalah terdapat pengaruh terapi kognitif perilaku religius dalam menurunkan kecemasan terhadap kematian pada penderita HIV/AIDS. Kecemasan terhadap kematian penderita HIV/AIDS menurun setelah diberikan terapi kognitif perilaku religiositas. 


\section{METODE PENELITIAN}

\section{Subjek Penelitian}

Subjek pada penelitian ini berjumlah 8 orang penderita HIV/AIDS berjenis kelamin perempuan.

\section{Desain Penelitian}

Penelitian ini merupakan penelitian eksperimen, dengan rancangan eksperimen pre-test post-test control group design.

Rancangan eksperimen yang digunakan dalam penelitian ini adalah:

Tabel 1. Rancangan Eksperimen

\begin{tabular}{cccc}
\hline Kelompok & Prates & Perlakuan & Pascates \\
\hline KE & Y1 & $\mathrm{X}$ & Y2 \\
KK & Y1 & $-X$ & Y2 \\
\hline
\end{tabular}

\section{Keterangan :}

KE : Kelompok eksperimen

Y1 : Pengukuran prates

Y2 : Pengukuran pascates

$\mathrm{X}$ : Perlakuan

- X : Tanpa perlakuan

\section{Metode Pengumpulan Data}

Langkah-langkah yang dilakukan peneliti dalam melakukan pengumpulan data ini adalah (1) Penyusunan Skala Kecemasan terhadap Kematian,

Wawancara, (4) Observasi.

\section{Prosedur Intervensi}

Persiapan Penelitian. Persiapan penelitian ini meliputi pelaksanaan need assessment melalui wawancara dengan anggota dan pimpinan LSM HIV/AIDS, pengurusan perizinan, penyusunan rancangan penelitian dan modul terapi kognitif perilaku religius, seleksi terapis, ko-terapis, dan observer, persiapan terapis untuk melakukan terapi, penentuan subjek penelitian, penyusunan skala dan uji coba skala, uji coba modul penelitian, dan terakhir penandatanganan persetujuan dan screening subjek.

Pengukuran Awal. Pengukuran awal ini dimaksudkan untuk mengetahui tingkat kecemasan terhadap kematian subjek penelitian sebelum perlakuan, yang akan dibandingkan dengan hasil pengukuran setelah pemberian perlakuan. Alat ukur yang digunakan dalam prates ini berupa skala kecemasan terhadap kematian.

Tahap Pemberian Perlakuan. Aplikasi dalam mengatasi kecemasan terhadap kematian akan diterapkan dengan memberikan pekerjaan rumah setiap hari untuk menerapkan keterampilan yang diajarkan. Pelaksanaan program ini dibantu oleh satu tenaga psikolog sebagai tenaga profesional. Psikolog didampingi oleh ko-terapis dan peneliti sekaligus sebagai observer. Pemberian terapi dilaksanakan secara berkelompok selama lima sesi, setiap minggu dua kali sesi, setiap pertemuan dilaksanakan selama 60-100 menit. Selama mendapat terapi, subjek diberi tugas-tugas untuk dikerjakan sebagai pekerjaan rumah dan akan dibahas selama terapi. 


\section{Teknik Analisis Data}

Analisis data yang digunakan dalam penelitian ini adalah analisis kuantitatif dan kualitatif. Analisis data kuantitatif untuk menguji hipotesis dilakukan dengan menggunakan analisis statistik Non Parametrik Mann-Whitney Test. Teknik ini bertujuan untuk melihat perbedaan tingkat kecemasan terhadap kematian akibat adanya perbedaan hasil sebelum perlakuan (prates), setelah perlakuan (pascates), dan tindak lanjut (follow-up) antara kelompok eksperimen yang mendapatkan terapi kognitif perilaku religius dengan kelompok kontrol.

Analisis kualitatif bertujuan untuk menjelaskan dinamika psikologis proses terapi kognitif perilaku religius yang terjadi pada masing-masing subjek yang mendukung analisis kuantitatif yang telah dilakukan sebelumnya. Analisis data secara kualitatif dilakukan berdasarkan hasil observasi, wawancara, lembar kerja, monitor diri buku harian dan berbagi pengalaman (sharing) dan lembar kerja yang diisi di rumah.

\section{HASIL PENELITIAN}

\section{Deskripsi Data Penelitian}

Data dalam penelitian mendeskripsikan 8 subjek penelian yang terdiri atas 4 orang subjek kelompok eksperiman yang diberi perlakuan dan 4 orang kelompok kontrol yang mendapatkan perlakuan di akhir penelitian. Deskripsi data penelitian yang diperoleh dari hasil pengukuran awal (prates), pengukuran akhir (pascates) dan pengukuran ulang setelah perlakuan (follow-up). Deskripsi data kelompok eksperimen dan kelompok kontrol dapat dilihat pada tabel berikut :

Tabel 1. Deskripsi Statistik Kecemasan Kelompok Eksperimen Saat Prates, Pascates, dan Follow-up

\begin{tabular}{ccccccc}
\hline \multirow{2}{*}{ Nama } & \multicolumn{2}{c}{ Prates } & \multicolumn{2}{c}{ Pascates } & \multicolumn{2}{c}{ Follow-up } \\
\cline { 2 - 7 } & Skor & Ketegori & Skor & Ketegori & Skor & Ketegori \\
\hline KR & 113 & Tinggi & 77 & Sedang & 86 & Sedang \\
LT & 96 & Tinggi & 91 & Sedang & 100 & Sedang \\
FR & 79 & Sedang & 48 & Rendah & 50 & Rendah \\
IK & 84 & Sedang & 60 & Rendah & 59 & Rendah \\
\hline
\end{tabular}


Tabel 2. Deskripsi Statistik Ketegori Kecemasan Kelompok Control Saat Prates, Pascates, dan Follow-up

\begin{tabular}{ccccccc}
\hline \multirow{2}{*}{ Nama } & \multicolumn{9}{c}{ Pratest } & \multicolumn{2}{c}{ Pascates } & \multicolumn{2}{c}{ Follow-up } \\
\cline { 2 - 7 } & Skor & Ketegori & Skor & Ketegori & Skor & Ketegori \\
\hline YL & 89 & Sedang & 101 & Tinggi & 80 & Sedang \\
CR & 93 & Tinggi & 95 & Tinggi & 85 & Sedang \\
YN & 93 & Tinggi & 115 & Tinggi & 112 & Tinggi \\
NY & 88 & Sedang & 109 & Tinggi & 103 & Tinggi \\
\hline
\end{tabular}

Berdasakan perolehan skor dan kategori seperti pada tabel di atas diketahui subjek penelitian baik kelompok kontrol dan kelompok eksperiman memiliki kecemasan yang tergolong sedang sampai dengan sangat tinggi.

Setelah diberi terapi kognitif perilaku religius ada perbedaan yang signifikan antara kelompok kontrol dengan kelompok eksperimen. Kelompok eksperimen memiliki kecemasan yang lebih rendah dibandingkan dengan kelompok kontrol. Berdasarkan perolehan skor dan ketegori seperti pada kedua tabel di atas diketahui subjek penelitian pada kelompok kontrol yang tidak mendapatkan terapi kognitif perilaku religius masih mempunyai kecemasan yang tergolong tinggi sedangkan kelompok eksperimen setelah mendapatkan terapi kognitif perilaku religius semua mengalami penurunan tingkat kecemasan terhadap kematian yang cukup drastis. Hal ini menunjukkan ada penurunan yang signifikan sebelum dan sesudah pemberian terapi kognitif perilaku religius pada kelompok eksperimen.
Hasil saat tindak lanjut (follow-up), yaitu pengukuran ulang kecemasan terhadap kematian pada kelompok eksperimen setelah satu bulan mendapatkan terapi kognitif perilaku religius diketahui tidak ada kategori penurunan kecemasan terhadap kematian pada semua subjek, sedangkan pada kelompok kontrol ada dua subjek yang mengalami kategori penurunan kecemasan terhadap kematian, sedang dua orang subjek lagi tidak mengalami perubahan kategori kecemasan terhadap kematian yaitu masih dalam kategori tinggi.

\section{HASIL}

Hipotesis dalam penelitian ini adalah ada pengaruh terapi kognitif perilaku religius terhadap pengurangan kecemasan terhadap kematian pada subjek penderita HIV/AIDS. Ada perbedaan penurunan kecemasan terhadap kematian antara sebelum dan sesudah diberikan terapi.

Pengujian hipotesis dilakukan dengan uji statistik Non Parametrik Mann-Whitney Test. Hasil analisis data dengan uji MannWhitney Test terdapat pada tabel. 
Tabel 3. Rangkuman Uji Mann-Whitney Test

\begin{tabular}{lccc}
\hline Pengukuran & $\mathbf{Z}$ & $\mathbf{p}$ & Keterangan \\
\hline Prates - Pascates & $-2,309$ & 0,021 & Signifikan \\
Pascates - Follow-up & $-2,323$ & 0,020 & Signifikan \\
\hline
\end{tabular}

Tabel 3 menunjukkan bahwa pada prates dan pascates ada perbedaan kecemasan yang signifikan pada subjek penelitian, hal ini ditunjukkan dengan nilai $Z=-2,309, p=0,021(p<0,05)$. Pada posttest dan follow-up ada perbedaan kecemasan pada subjek penelitian, hal ini ditunjukkan dengan nilai $\mathbf{Z}=$ -2,323, $p=0,020(p<0,05)$. Dari hasil uji Hipotesis dapat disimpulkan bahwa terdapat perbedaan kecemasan yang signifikan setelah diberikan terapi pada subjek penelitian dan ada perbedaan tingkat kecemasan terhadap kematian pada subjek penelitian setelah dilakukan follow-up.

\section{PEMBAHASAN}

Penelitian ini bertujuan untuk melihat apakah terapi kognitif perilaku religius berhasil menurunkan kecemasan terhadap kematian pada penderita HIV/ AIDS. Hasil penelitian ini secara umum menemukan bahwa terapi kognitif perilaku religius mampu membantu penderita HIV/AIDS dalam menurunkan kecemasan terhadap kematian. Hasil analisis statistik non parametrik terhadap uji hipotesis menyatakan ada perbedaan yang signifikan pada tingkat kecemasan terhadap kematian antara kelompok eksperimen penderita HIV/AIDS yang diberi terapi kognitif perilaku religius dengan kelompok kontrol pada penderita HIV/AIDS yang tidak diberi terapi kognitif perilaku religius. Hasil ini berlaku pada kelompok eksperimen dalam penelitian ini dan belum bisa digeneralisasikan pada kelompok di luar eksperimen. Pemberian terapi kognitif perilaku religius efektif dalam menurunkan tingkat kecemasan terhadap kematian pada penderita HIV/ AIDS.

Berdasakan perolehan skor dan kategori seperti pada tabel sebelumnya diketahui bahwa pada saat tindak lanjut (follow-up), yaitu pengukuran ulang kecemasan pada kelompok eksperimen setelah 3 minggu mendapatkan terapi kognitif perilaku religius diketahui ada penurunan skor kecemasan terhadap kematian yang signifikan pada empat subjek, sehingga kecemasannya pun mengalami penurunan dari kategori sangat tinggi menjadi sedang, meskipun demikian ada subjek lain yang hanya mengalami perubahan dari sedang ke rendah.

Hasil penelitian menunjukan adanya penurunan yang signifikan tingkat kecemasan terhadap kematian pada saat sebelum dan sesudah intervensi terapi. 
Penyebabnya adalah kesungguhan dan keseriusan para peserta terapi dalam mengikuti program intervensi. Adanya penurunan tingkat kecemasan terhadap kematian dari para peserta juga tidak lepas dari dari pengaruh tahapantahapan yang saling berhubungan, sehingga subjek selama proses terapi merasakan langsung manfaat dari setiap sesi pelaksanaan program terapi ini. Hal yang bersifat positif yang dirasakan subjek dari setiap sesi dalam pelaksanaan intervensi membuat subjek memahami manfaat langsung dari terapi ini. Subjek yang selama ini sering merasakan kecemasan dengan berbagai macam permasalahan yang menimbulkannya, mulai memperoleh manfaat langsung seperti hilangnya kesedihan, gangguan tidur, gangguan nafsu makan, takut, marah dan malu, semua hal-hal negatif yang sering muncul berangsur-angsur mengalami penurunan termasuk berbagai keluhan fisik yang mereka alami tersebut. Pada penelitian Leake dkk (1999) bahwa strategi presentasi diri tampak efektif dalam meningkatkan penyesuaian diri, belajar untuk menerima pendapat, belajar mendengarkan, memberikan umpan balik dari peserta yang lain karena dapat menolong peserta berdamai dengan masalah mereka sendiri. Hal ini semakin menunjukan bahwa terapi kognitif perilaku-religius efektif dalam mengatasi masalah terkait dengan kecemasan dan pendekatan yang digunakan juga mencakup semua aspek yaitu kognisi, afeksi dan perilaku sehingga dalam penelitian ini peneliti menggunakan terapi kognitif perilaku dalam kelompok untuk menurunkan tingkat kecemasan terhadap kematian pada penderita HIV/ AIDS.

Selain itu faktor di atas keaktifan individu dalam melaksanakan prosedur terapi dirumah juga berpengaruh terhadap kondisi kecemasan subjek. Semakin rajin atau aktif subjek dalam melaksanakan anjuran-anjuran selama mengikuti terapi maka akan semakin menurunkan tingkat kecemasan yang dialami begitu pula sebaliknya.

Kondisi atau situasi yang menjadi stressor juga mempengaruhi kecemasan subjek. Misalnya ketika kondisi fisik subjek menurun maka akan berpengaruh pada suasana hati, dan aktivitas lain juga akan terganggu. Hal ini terkait dengan state anxiety cenderung tidak stabil dan ketika ada kondisi tertentu dapat meningkatkan kecemasan (Rice, 1999). Subjek LT mengalami kenaikan tingkat kecemasan terhadap kematian saat pascates. Hal tersebut karena kondisi subjek sedang flu, anaknya rewel dan menangis terus pada saat diajak tes, sehingga sangat memengaruhi suasana hatinya.

Ketika pola pikir negatif itu berkembang pesat dalam diri penderita HIV/AIDS. Menurut Beck dkk (1974) setidaknya ada 3 kemungkinan yang muncul dalam pikiran penderita HIV/ AIDS. Pertama pendangan negatif tentang 
diri sendiri, pada kondisi ini penderita HIV/AIDS merasa tidak berharga, sudah rusak, merasa tidak mampu lagi melakukan aktivitas, dan kehadirannya tidak diharapkan lagi. Kedua, pandangan negatif tentang dunia dan lingkungannya, pada kondisi ini penderita HIV/ AIDS memandang bahwa dunia dan sekitarnya sebagai kelompok yang tidak peka, menghukum, dan menyudutkan keberadaan penderita sehingga penderita HIV/AIDS melihat dunia secara pesimis dan sinis. Ketiga pandangan negatif tentang masa depan, pada kondisi ini penderita menganggap masa depan sebagai sesuatu yang sia-sia dan tidak memberikan sedikitpun harapan, selain itu penderita akan selalu berpikir sampai disini tapi selalu berkelanjutan. Kecemasan kognitif merupakan sebuah kesulitan dalam konsentrasi, berpikir, dan gangguan dalam berpikir atau distorsi kognitif.

Kelebihan lain dari terapi ini adalah dalam mekanisme pelaksanaannnya dapat dikembangkan sebagai suatu bentuk strategi treatmen yang inovatif dan hasilnya lebih efektif, efisien serta menghemat biaya (Fairburn, dkk., 2002). Oemarjoedi (2004) menambahkan bahwa tujuan terapi berpikir juga mengajak klien untuk menentang pikiran (dan emosi) yang salah dengan menampilkan bukti-bukti yang bertentangan dengan keyakinan mereka tentang masalah yang dihadapi. Proses pemberian terapi selama ini biasanya diberikan oleh psikolog maupun psikiater atau disebut profesional, sebagai bentuk kewenangan profesi, sebagaimana penelitian-penelitian yang dilakukan. Bahkan pada beberapa keahlian mengharuskan pendidikan tambahan setelah memperoleh kesarjanaannya, seperti untuk menjadi seorang psikolog atau psikiater harus mengikuti program pendidikan dan latihan tambahan yang kompleks secara formal selama dua sampai enam tahun. Bahkan sebenarnya untuk menjadi profesional di bidang psikologi dibutuhkan kompensasi sederajat doktor dengan spesialis psikologi klinis atau psikologi konseling. Mereka yang profesional memliki kemampuan untuk mengurangi atau meringankan ketidaknyamanan dan masalah-masalah psikologis.

Kepasrahan adalah salah satu strategi yang dilakukan oleh subjek dalam menghadapi kematiannya. Memilih untuk pasrah merupakan salah satu bentuk emotional-focused coping. Emotionalfocused coping adalah strategi di mana individu memilih untuk melepasan perasaan-perasaan negatif seperti marah, frustasi, serta cemas yang diakibatkan suatu peristiwa (Rice, 1999). Jenis coping ini terlihat lebih menonjol ketika individu menyimpulkan bahwa hanya sedikit atau bahkan tidak terlihat sama sekali hal yang bisa dilakukan terhadap situasi tersebut. Situasi yang dihadapi subjek tidak bisa berubah. Biar bagaimanapun, statusnya sebagai ODHA cepat atau lambat akan mendatangkan kematian. 
Teknik lain yang diajarkan kepada subjek adalah relaksasi yang dalam penelitian ini difokuskan pada relaksasi dengan religius. Relaksasi ini bertujuan untuk mengatasi gejala-gejala fisiologis yang timbul karena kecemasan dan subjek dilatih untuk melakukan relaksasi tersebut di rumah saat menghadapi situasi-situasi yang menimbulkan kecemasan terhadap kematian, subjek cenderung mengulangi latihan relaksasi ketika merasakan efek nyaman yang ditimbulkan (Greenberger \& Padesky, 1995). Semua subjek mengatakan dapat merasakan efek relaksasi, bahwa dengan relaksasi dirinya merasa lebih tenang, merasa nyaman, pikiran tenang dan semangat menjalani hidup.

Dari teori di atas dapat diberi ulasan bahwa tinggi rendahnya kecemasan semata-mata tidak karena faktor terapi saja, namun terkait faktor-faktor lain seperti disebutkan tokoh di atas. Penelitian ini mendukung beberapa penelitian mengenai pengaruh terapi kognitif perilaku yang telah dilakukan oleh peneliti sebelumnya. Penelitian yang dilakukan oleh Barrowclough dkk (2001) meneliti tentang gangguan kecemasan pada orang dewasa lanjut yang berusia antara 55 hingga 72 tahun. Penelitian ini menguji efektifitas terapi kognitif perilaku untuk menurunkan gangguan kecemasan pada subjek orang dewasa lanjut dengan menggunakan terapi kognitif perilaku dan Supportive Counseling (SC). Tritmen terapi kognitif perilaku yang digunakan adalah latihan relaksasi, desentisasi sistematis, explosure, flooding, prevensi respon, dan restrukturisasi kognitif. Hasil penelitian menunjukkan bahwa CBT efektif digunakan untuk menangani gangguan kecemasan pada orang dewasa lanjut dan manfaat yang diamati pada akhir terapi dapat dipertahankan hingga 12 bulan masa follow-up. Walaupun hasil penelitian menunjukkan SC juga efektif secara signifikan dalam menurunkan tingkat kecemasan, namun terapi CBT menunjukkan terhadap tritmen pada kelompok SC efektif sebanyak 39 persen pada 12 bulan masa follow-up. Respon tersebut masih lebih bila dibandingkan dengan respon subjek terhadap tritmen pada kelompok CBT yang menunjukkan angka $71 \%$. Kemampuan intervensi CBT untuk menghasilkan efek yang baik pada pasien dewasa lanjut menimbulkan beberapa optimisme terkait dengan tritmen psikologis untuk menangani gangguan kecemasan tersebut.

\section{SIMPULAN DAN SARAN}

\section{Simpulan}

Berdasarkan hasil penelitian dapat disimpulkan bahwa terapi kognitif perilaku religius berpengaruh dalam menurunkan kecemasan terhadap kematian pada penderita HIV/AIDS. Hasil observasi, wawancara dan penilaian kecemasan melalui skala menunjukan bahwa ada perbedaan tingkat kecemasan terhadap kematian sebelum dan sesudah 
diberi perilaku, sampai dengan follow-up. Secara perasaan subjek menjadi peka, lebih tenang, lebih bahagia, merasa nyaman, bisa menerima diri mampu menilai positif pada diri sendiri, masa depan, dan lingkungan dan Secara perilaku subjek menjadi lebih percaya diri, lebih bersabar, periang, tidak mengalami kesulitan tidur, nafsu makan kembali ada, lebih rajin beribadah, lebih bersemangat dalam menjalani hidup dan mau bersosialisasi kembali dengan lingkungan, lebih stabil dan lebih berani

Berdasarkan analisis individual didapatkan beberapa faktor yang mempengaruhi dalam penurunan kecemasan pada penderita HIV/AIDS antara lain karena faktor kedisiplinan dalam mengerjakan pekerjaan rumah, melakukan latihan secara rutin dan teratur, kondisi fisik dan psikis subjek, di samping itu faktor lingkungan tempat berlangsungnya terapi dan tempat tinggal subjek juga sangat mempengaruhi hasil terapi.

\section{Saran}

Berdasarkan pelaksanaan pene-litian dan hasil yang diperoleh, saran yang dapat disampaikan oleh peneliti adalah sebagai berikut:

1. Kepada penderita HIV/AIDS

Agar dapat memanfaatkan secara maksimal terapi yang diikuti, serta dapat diaplikasikan dalam kegiatan sehari-hari meskipun tanpabimbingan terapis. Ada baiknya penderita HIV/
AIDS dapat meningkatkan kualitas hidupnya dengan cara meningkatan intensitas dan frekuensi dukungan sosial yang dirasa dalam usaha untuk melakukan prosedur pengobatan dan berupaya untuk tetap berpikir dan berperilaku positif dalam menjalani kehidupan, sehingga dapat mencapai kondisi kesehatan yang lebih baik.

2. Kepada petugas kesehatan rumah sakit

Pada instansi kesehatan terkait seperti puskesmas sebaiknya perlu diadakan tes/pemeriksaan HIV/ AIDS bagi para calon pengantin baik untuk laki-laki atau perempuannya, sehingga bila memang salah satu pihak ada yang terinfeksi virus ini bisa dilakukan pencegahan lebih dini dan pembekalan yang lebih mendalam.

3. Kepada LSM yang berwenang

Terapi kognitif perlu dipertimbangkan sebagai salah satu metode terapi kelompok yang cukup layak untuk dipergunakan dalam proses meningkatkan kekebalan tubuh para penderita HIV/AIDS, khususnya dalam hal mengendalikan dan meminimalisasi kecemasan terhadap kematian pada para penderita HIV/AIDS.

4. Kepada peneliti selanjutnya

Diharapkan dapat melakukan penelitian lanjutan dengan memperhatikan dan mengatasi kele-mahan dan kekurangan dalam penelitian ini, khususnya dalam hal memperbanyak 
jumlah dan variasi subjek, misalnya tingkat status sosial, ekonomi, dan penderita yang mempunyai keturunan HIV/AIDS. Perlu uga untuk memperhatikan upaya penguatan pada subjek dalam mengerjakan tugas pekerjaan rumah secara teratur dan rutin, sebab tugas akan membantu subjek dalam memonitor perubahan dan perkembangan terapi yang diikutinya. Perlu dipersiapkan tempat yang bersih dan tenang saat pemberian intervensi, jauh dari suasana bising, dan dianjurkan untuk tidak membawa anak kecil saat berlangsungnya terapi.

\section{DAFTAR PUSTAKA}

Adelbratt, S. \& Strang, P. (2000). Death Anxiety In Brain Tumor Pattiens And Their Spouses. Palliative Medicine. Vol 14, 499-507. Diunduh dari http://proquest.umi.com/pqdweb?

Beck, A. T., Laude, R. \& Bohnert, M. (1974). Ideational Components of Anxiety Neurosis. Archieves of General Psychiatry, 31, 319-26.

Barrowclough, C., King, P., Colville, J., Russell, E., Burns, A., \& Tarrier, N. (2001). A Randomized Trial of the Effectiveness of Cognitive-Behavior Therapy and Supportive Counseling for Anxiety Sympton in Older Adults. Journal of Counsulting and Clinical Psychology, 69 (5), 756-762.
Benson, H. M. D., (2000). Dasar-dasar Respon Relaksasi: Bagaimana Menggabungkan Respon Relaksasi dengan Keyakinan Pribadi Anda (terjemahan). Bandung: Mizan.

Chung, C. M., \& Easthope, Y. (2000). Traumatic Stress and Death Anxiety among Community Residents Exposed to an Aircraft Crash. Academic Research Library. Vol 24 (8), 869. Diunduh dari http: //proquest. umi.com/pqdweb.

Djauzi, S. (1997). Penatalaksanaan Infeksi HIV. Jakarta: Departemen Kesehatan.

Djoerban, Z. (1999). Membidik AIDS, Ikhtisar Pemahaman HIV dan ODHA. Yogyakarta: Galang Press.

Fairburn, A. S., Wood C. H. \& Fletcher C. M. (2002) Variability in Answers to a Questionnaire on Respiratory Symptoms British. Journal of Preventive and Social Medicine, 13, 175-193.

Feifel, H. \& Nagy, V. T. (1981).Another Look at Fear of Death. Journal of Consulting and Clinical Psychology, 49(2), 278-286.

Froggatt, W. (2006). A Brief Introduction to Cognitive-Behavior Therapy. Journal Cognitive-Behavior Therapy. Diunduh dari http://www.rational. org.nz.

Green, C.W. (2003). Pengobatan untuk AIDS: Ingin Mulai? Jakarta: Yayasan Spiritia. 
Greenberger, D \& Padesky, C. A. (1995). Mind over Mood: Change how you feel by Changing the Way you think. New York: The Guliford Press.

Hawari, D. (2006). Al-Quran Ilmu Kedokteran Jiwa dan Kesehatan Jiwa. Yogyakarta: Dana Bhakti Prima Yasa.

Kastenbaum, R. \& Aisenbergh, R. (1976). The Psychology of Death; Concise Edition. New York: Springer Publishing Company.

Keefe, F.J., Dunsmore, J. \& Burnett, R. (1992).Behavioral and Cognitive behavioral approaches to chronic pain: Recent advances and future direction. Journal of Consulting and Clinical Psychology, 60, 4, 528-536.

Kimmel, D.C., (1980). Adulthood and Aging.An Interdiciplinary Developmental View.Second Edition.USA: John Wiley and Sons, Inc.

Puji B., Siwi Tri (2010). Penderita HIV Meningkat. Republika Online. Diakses 3 Desember 2010.

Leake, R., Friend, R., \& Wadhwa, N. (1999). Improving Adjustment to Chronic Illness Through Strategic Self Presentation: An Experimental Study on Arenaldyalisis Unit. Health Psychology, 18 (1), 54-62.

Maramis, M.M., \& Nasrudin. (2007). Konseling dan Tes Sukarela untuk Penderita HIV/AIDS. Konseling, Dukun- gan, Perawatan, dan Pengobatan ODHA. Surabaya: Airlangga University Press.

Meichenbaum, D. (1989). Cognitive Behavior Modification. In Kanfer, F.H. \& Goldstein, A.P (Eds), Helping People Change: A Textbook Method. Oxford: Pergamon Press.

Najati, M. U. (1985). Al-Quran dan IImu Jiwa. Bandung: Penerbit Pustaka.

Oemarjoedi, A. K. (2004). Pendekatan Cognitive Behavior dalam Psikoterapi. Jakarta: Penerbit Creativ Media.

Pargament, K. I; Smith, B.W; Koenig, H. G; \& Perez, L (1998). Patterns of Positif and Negative Religius Coping with Major Life Stressors. Journal for the Scientific Study of Religion, 37, 710-742.

Rice, P. L. (1999). Stress and Health. New York: Brooks/Cole Publishing Company.

Subuh, M. (2010).Gawat! Ada 1,6 juta Istri Rentan Tertular HIV/AIDS. Republika Online.Diakses 28 Desember 2010.

Wicaksono, W. (2003).Ketakutan Terhadap Kematian Ditinjau dari Kebijaksanaan dan Orientasi Religius pada Periode Remaja Akhir yang Berstatus Mahasiswa.Tesis (Tidak diterbitkan). Yogyakarta: Fakultas Psikologi UGM. 